\title{
Impact of Packaging on Consumer Buying Behavior at Dhaka City
}

\author{
Wahida Shahan Tinne \\ Senior Lecturer, Faculty of Business, ASA University Bangladesh, Dhaka, BANGLADESH \\ *Corresponding Contact: \\ Email: tinne_4066@yahoo.com
}

\begin{abstract}
Package becomes an ultimate selling proposition stimulating impulse buying behavior, increasing market share and reducing promotional costs. Packaging is known as the physical appearance of the product that includes design, color, shape, label and materials of a product. It is also used as a marketing tool to get the consumers' attention. Packaging is considered as all the activities of designing and producing the container for a product. Due to changing consumers' life-style and increasing self-service, the packaging is considered as fifth ' $\mathrm{P}$ ' along with the other 4 ps - product, price, place, and promotion. The main objective of this paper is to find out the impact of packaging on consumers at Dhaka city in Bangladesh. The logit analysis is used to identify the impact of packaging on consumer buying behavior. The researcher has identified seven variables that found in previous researches of the impact of packaging. The dependent variable is Consumer Buying Behavior Dependent on Packaging. The independent variables are Packaging Color, Background Image, Packaging Material, Font Style, Design of Wrapper, Printed Information and Innovation. The questionnaire is designed on Likert Scale where consumers are asked to put a tick mark on seven statements. These seven statements are selected based on variables that found in previous researches of the impact of packaging. The sampling technique is non-probability sampling. The researcher tries to find out customers who have shown interest in survey and respondents are asked questions who usually take major purchase decisions for the family consumption. So in this study, convenience sampling is applied. The sample size is 120. Sampling Area is Banani, Dhanmondi, Gulshan, and Shyamoli. It is focused on the specific areas only. It can be done in an extensive way. The sample can be large. Statistical tools SPSS is used to find out the relationship of the hypothesis of the impact of packaging on consumers of Dhaka city in Bangladesh.
\end{abstract}

Key Words: Consumer Buying Behavior, Packaging Color, Background Image, Packaging Material, Font Style, Design of Wrapper, Printed Information and Innovation

\section{INTRODUCTION}

The jam bottle refuses to open as per the instructions. The flour goes stale when the inner bag tears or does not reseal securely. The last bit of toothpaste or shampoo that is retrievable 
only by balancing the bottle upside down for a while. These are few examples of packages that do not always do what we want them to do. Packaging is a key component of marketing, according to recent studies by the Point of Purchase and Advertisement Institute (POPAI), which indicate that $70 \%$ of consumers buying decisions are made at the point of sale. Recently the marketing environment has become increasingly complex and competitive, and the role of packaging has changed due to the increment of self-service and changing consumers' lifestyle.

Package becomes an ultimate selling proposition stimulating impulse buying behavior, increasing market share and reducing promotional costs. Packaging encompasses the physical appearance of the container and includes the design, color, shape, label and materials used (Deliya, 2012). Packaging has a huge role to play in the positioning of the products. The perception of the consumer is shaped by package design. Sometimes it can be the determining factor in point-of-purchase decisions. Sometimes the packaging is more influential than advertising. Initially, packaging was intended largely to provide protection to the product. With its increasing significance in marketing, it has become a major factor in gaining customers.

\section{LITERATURE REVIEW}

The importance of packaging has been increased due to the function of protecting the products from the damage, mishandling and deterioration. In today's competitive environment, it is also used as a marketing tool to get the consumers' attention. Due to changing consumers' life-style and increasing self-service, the packaging is considered as fifth ' $\mathrm{P}$ ' along with the other 4ps - product, price, place, and promotion (Kotler, 2004). The most common types of packaging materials are glass, metals, plastics, paper and board (Silayoi \& Speece, 2004). The package's overall features can underlie the uniqueness and originality of the product. Quality judgments are highly influenced by product characteristics reflected by packaging (Silayoi \& Speece, 2004). High-quality of packaging leads to high pricing of the product and consumers assume that the product is of high quality. Low-quality of packaging symbolizes low pricing, consumer think of low-quality to the product itself. Packaging helps the consumer to decide the first impression regarding the product (Rundh, 2005). Consumers most time are attracted at first sight to the packaging style of a product (Terblanche, 2006).

According to Smith and Taylor (2004), there are six variables that must be taken into consideration by producers and designers when creating the efficient package: form, size, color, graphics, material and flavor. Consumer buying behavior deals with cognitive and affective orientations in the process of decision-making. Four important packaging elements affect consumer purchase decisions, which can be separated into two categories: informational and visual elements (Silayoi \& Speece, 2004). The visual elements consist of graphics and size/shape of packaging and relate more to the affective side of decisionmaking. In 2008, Butkeviciene, Rutelione and Stravinskiene distinguished between nonverbal elements of the package (color, form, size, imageries, graphics, materials and smell) and verbal elements of the package (product name, brand, producer, country of origin, information, special offers and instruction of usage). Good and attractive packaging may add value to the product and attract a trial from customers (Scott, 2008).

The consumer buying behavior on package elements can be stronger or weaker depending on the consumer's involvement level, time pressure or individual characteristics of consumers (Dovaliene, Kuvykaite \& Navickiene, 2009). Visual elements of the package have a stronger effect on consumers when they are in the level of low involvement. Conversely, verbal elements of the package have a greater impact on consumers who are in the level of 
high involvement (Dovaliene, Kuvykaite \& Navickiene, 2009). Visual elements of the package have a stronger impact on product selection when consumers are under time pressure, and conversely when consumers are not under time pressure, verbal elements of the package have a higher influence (Dovaliene, Kuvykaite \& Navickiene, 2009). Previous researches also deal with gender, age, education and occupation to reveal the influence of packaging on consumers when making a purchase decision for convenience goods.

Product's brand name, manufacturer name and country of origin, graphics and nutritional information are important in consumer buying decision process (Badrie \& Peters-Texeira, 2007). Certain packaging colors set different moods and can help to draw attention (Blythe, 2008). Yellow indicates cheap, cheerful and warmth. It works well as the background color for black print. Orange is sociable color and mainly used for products that made up of orange. Red signifies exciting, passionate and strong, works well in cosmetics. Purple is used to identify royalty and up-market image. Blue indicates coolness, cleanliness and having authority. It is used in masculine products. Green means natural, security and calmness. Pink or Magenta is feminine color and used in cosmetics, sometimes used in baby products too. White indicates purity and cleanliness. Brown is used as strong flavors, especially in food products like chocolates, pickles, sauces. Black combined with gold can represent exclusivity and premium prices. Grey indicates sadness, transition, and compromise, mainly used in high-tech products and modern designs.

Nowadays, innovative packaging includes portion control, recyclability, tamper-proofing, childproofing, easy-open, easy-store, easy-carry and no breakability (Deliya and Parmar, 2012). Consumers use information on product packaging for choosing a product over competing products. Firm's product packaging should influence the consumer buying decisions. Many companies spend a lot more money on advertising than on packaging. But packaging is considered very important because, it serves as an advertising medium (Lifu, 2012).

\section{OBJECTIVE OF THE STUdY}

By the gap found in the literature review, the main objective of the study is to find out the impact of packaging on consumer buying behavior at Dhaka city in Bangladesh. To achieve the main objective, the following sub-objectives are set:

- To study the relationship between packaging elements and consumer buying behavior.

- To find out the important packaging factors for consumer's purchase at retail stores.

- To make suggestions to increase sales of products through packaging at retail stores.

\section{Methodology}

The logit analysis is used to identify the impact of packaging on consumer buying behavior. From the literature review, the researcher has identified seven variables that found in previous researches of the impact of packaging. The dependent variable is Consumer Buying Behavior Dependent on Packaging. The independent variables are Packaging Color, Background Image, Packaging Material, Font Style, Design of Wrapper, Printed Information and Innovation. Seven hypotheses are developed:

$\mathrm{H}_{1}$ : There is relationship between consumer buying behavior and packaging color $\mathrm{H}_{2}$ : There is relationship between consumer buying behavior and background image $\mathrm{H}_{3}$ : There is relationship between consumer buying behavior and packaging material $\mathrm{H}_{4}$ : There is relationship between consumer buying behavior and font style 
$\mathrm{H}_{5}$ : There is relationship between consumer buying behavior and design of wrapper $\mathrm{H}_{6}$ : There is relationship between consumer buying behavior and printed information $\mathrm{H}_{7}$ : There is relationship between consumer buying behavior and innovation

The study is conducted based on two sources of information: primary and secondary sources. At first, some general information regarding customers is asked in a questionnaire like name, age, gender, occupation, etc. (questionnaire is given in Appendix). Next part of the questionnaire is designed on Likert Scale (Strongly Agree = 5, Agree = 4, Neutral = 3, Disagree $=2$ and Strongly Disagree $=1$ ) where consumers are asked to put a tick mark on seven statements. These seven statements are selected based on variables that found in previous researches of the impact of packaging. The questionnaire is used to collect primary source of information. Websites, articles, and books are the secondary sources of information.

In this paper, researcher chooses the customers who regularly roam at different retail stores. The sampling technique is non-probability sampling, so samples are decided on the personal judgment of the researcher. The researcher tries to find out customers who have shown interest in survey and respondents are asked questions who usually take major purchase decisions for the family consumption. So in this study, convenience sampling is applied. The sample size is 120. Sampling Area is Banani, Dhanmondi, Gulshan, and Shyamoli. Statistical tools SPSS is used to find out the relationship of hypothesis of the impact of packaging on consumers of Dhaka city in Bangladesh. There are some limitations in this paper. It is focused on the specific areas only. It can be done in an extensive way. The sample can be large.

\section{ANALYSIS AND INTERPRETATION OF DATA}

From the literature review, researcher finds out several variables which have significant influence of packaging on consumers. Seven statements are designed based on variables found from the literature review. Logit analysis is conducted on those variables.

\section{Demographic Profile}

In the questionnaire, respondents are asked about their gender, age, and occupation. The respondent, who purchases based on packaging, is considered as 'dependent on packaging.' The relationship of gender, age group and occupation with the pattern of the buyer (dependent or not on packaging) is shown in Table 1.

Table 1: Demographic Profile of Respondents

\begin{tabular}{|l|c|c|c|}
\hline & $\begin{array}{c}\text { Dependent } \\
\text { on Packaging }\end{array}$ & $\begin{array}{c}\text { Not Dependent } \\
\text { on Packaging }\end{array}$ & Total \\
\hline Gender: & & & \\
\hline Male & $34(55.7 \%)$ & $27(44.3 \%)$ & $61(100 \%)$ \\
\hline Female & $45(76.3 \%)$ & $14(23.7 \%)$ & $59(100 \%)$ \\
\hline Age Group: & & & \\
\hline $18-25$ & $14(58.3 \%)$ & $10(41.7 \%)$ & $24(100 \%)$ \\
\hline $26-35$ & $25(73.5 \%)$ & $9(26.5 \%)$ & $34(100 \%)$ \\
\hline $36-45$ & $35(74.5 \%)$ & $12(25.5 \%)$ & $47(100 \%)$ \\
\hline 46 and above & $5(33.3 \%)$ & $10(66.7 \%)$ & $15(100 \%)$ \\
\hline Occupation: & & & \\
\hline Business & $25(73.5 \%)$ & $9(26.5 \%)$ & $34(100 \%)$ \\
\hline Service & $33(68.8 \%)$ & $15(31.3 \%)$ & $48(100 \%)$ \\
\hline Others (Student, Housewife, etc) & $21(55.3 \%)$ & $17(44.7 \%)$ & $38(100 \%)$ \\
\hline
\end{tabular}


Among 120 respondents, 79 are dependent on packaging whereas 41 are not. From the Table 1, it is observed that females $(76.3 \%)$ concentrate more on packaging than males $(55.7 \%)$. In the case of age group, 26 to $45+$ are mostly dependent on packaging in case of consumer buying behavior. The respondent, who does business (73.5\%), is mostly dependent on the packaging.

\section{LOGIT ANALYSIS}

To continue towards the main analysis, logit analysis has been performed to identify the key dimensions of packaging on consumer buying behavior. In Table 2, Wald chi-square test is found. It tests the null hypothesis that the constant equals zero. This hypothesis is rejected because the p-value is smaller than the critical p-value of 0.05 . Usually, this finding is not necessary to the researcher.

Table 2: Variables in the Equation

\begin{tabular}{|l|l|l|l|l|l|l|l|}
\hline & & B & S.E. & Wald & df & Sig. & $\operatorname{Exp}(\mathrm{B})$ \\
\hline Step 0 & Constant & .656 & .192 & 11.611 & 1 & .001 & 1.927 \\
\hline
\end{tabular}

In Table 3, chi-square statistics and its significance level are stated. The statistics for the Step, Model and Block are the same because the researcher has not used stepwise logistic regression or blocking. The value given in the Significance column is the probability of obtaining the chisquare statistic given that the null hypothesis is true. In other words, this is the probability of obtaining this chi-square statistic (151.340) if there is, in fact, no effect of the independent variables, taken together, on the dependent variable. The $p$-value is a critical value, perhaps 0.05 or 0.01 to determine if the overall model is statistically significant. In this case, the model is statistically significant because the p-value is less than 0.00 .

Table 3: Omnibus Tests of Model Coefficients

\begin{tabular}{|l|l|l|l|l|}
\hline & & Chi-square & df & Sig. \\
\hline \multirow{2}{*}{$\begin{array}{l}\text { Step } \\
1\end{array}$} & Step & 151.340 & 7 & .000 \\
\cline { 2 - 5 } & Block & 151.340 & 7 & .000 \\
\cline { 2 - 5 } & Model & 151.340 & 7 & .000 \\
\hline
\end{tabular}

-2 Log likelihood is not very informative (Table 4). However, it can be used to compare reduced models. Cox \& Snell R Square and Nagelkerke R Square are pseudo R-squares (Table 4). There are a wide variety of pseudo R-square statistics, but these are only two of them. As it does not mean what R-squared means in OLS regression.

Table 4: Model Summary

\begin{tabular}{|l|l|l|l|}
\hline Step & -2 Log likelihood & Cox \& Snell R Square & Nagelkerke R Square \\
\hline 1 & $2.773 a$ & .717 & .991 \\
\hline
\end{tabular}

$B$ are the values for the logistic regression equation for predicting the dependent variable from the independent variable (Table 5). They are in log-odds units. P is the probability of being dependent on the packaging. So the logistic regression equation is,

$\log (p / 1-p)=-351.416+3.441^{*}$ packaging color - 1.277*background image $35.142^{*}$ packaging material $+2.379^{*}$ font style $+19.242^{*}$ design of wrapper $+53.105^{*}$ printed information $+51.276 *$ innovative of packaging

These estimates state the relationship between the independent variables and the dependent variable, where the dependent variable is on the logit scale. For every one unit increase in packaging color, it is expected a 3.441 increase in the log-odds of dependent on packaging, 
holding all other independent variables constant. For every one unit increase in the background image, it is expected a 1.277 decrease in the log-odds of dependent on packaging, holding all other independent variables constant. For every one unit increase in packaging material, it is expected a 35.142 decrease in the log-odds of dependent on packaging, holding all other independent variables constant. For every one unit increase in font style, it is expected a 2.379 increase in the log-odds of dependent on packaging, holding all other independent variables constant. For every one unit increase in the design of wrapper, it is expected a 19.242 increase in the log-odds of dependent on packaging, holding all other independent variables constant. For every one unit increase in printed information, it is expected a 53.105 increase in the log-odds of dependent on packaging, holding all other independent variables constant. For every one unit increase in innovative of packaging, it is expected a 51.276 increase in the log-odds of dependent on packaging, holding all other independent variables constant.

Table 5: Variables in the Equation

\begin{tabular}{|c|c|c|c|c|c|c|c|}
\hline & & B & S.E. & Wald & df & Sig. & $\operatorname{Exp}(B)$ \\
\hline \multirow[t]{8}{*}{ Step $1^{\mathrm{a}}$} & Packaging Color & 3.441 & $1.228 \mathrm{E} 4$ & .000 & 1 & 1.000 & 31.220 \\
\hline & Background Image & -1.277 & 6.050E3 & .000 & 1 & 1.000 & .279 \\
\hline & Packaging Material & -35.142 & 1.110E4 & .000 & 1 & .997 & .000 \\
\hline & Font Style & 2.379 & 6.346E3 & .000 & 1 & 1.000 & 10.794 \\
\hline & Design of Wrapper & 19.242 & 5.302E3 & .000 & 1 & .997 & 2.273E8 \\
\hline & Printed Information & 53.105 & 8.153E3 & .000 & 1 & .995 & $1.156 \mathrm{E} 23$ \\
\hline & Innovative of Packaging & 51.276 & $1.535 \mathrm{E} 4$ & .000 & 1 & .997 & 1.857E22 \\
\hline & Constant & -351.416 & $4.424 \mathrm{E} 4$ & .000 & 1 & .994 & .000 \\
\hline
\end{tabular}

\section{CONCLUSIONS AND RECOMmENDATIONS}

From the discussion, it is clear that attractive packaging of products significantly influences consumers' buying choice and stimulate impulse buying. It serves as advertising to consumers. In the trend of the present market environment, firms have to ensure the quality of their products and not just packaging to encourage repeated purchase from consumers. In Bangladesh, most of the consumers are influenced by packaging, but they prefer more protective, eco-friendly and convenience packaging. The brand name is highly related to packaging. Background image and packaging material are least preferred whereas packaging color, font style, the design of wrapper, printed information and innovative packaging are most preferred.

Due to the trend of retail stores, consumers of Bangladesh get enough time to examine and investigate products among lots of opportunities. In this case, packaging helps the consumer lot to take a quick decision regarding the choice of the products. Appropriate and vivid picture or packaging color delivers the consumers a happy feeling. Firms should develop innovative packages, and aesthetic components should be soothing for the eyes. Label information should be simplified and liked by the consumers. Moreover, the impact of package elements on consumers purchase decisions should be evaluated depending on the consumer's involvement level, time pressure or individual characteristics of consumers. Firms should pay attention for good packaging as poor packaging is one of the causes of product failure in the market. It is necessary to set the packaging standard and to implement accordingly for better protection and promotion of a product. 


\section{REFERENCES}

Badrie, N. and Peters-Texeira, A. (2007). Consumers' Perception of Food Packaging in Trinidad, West Indies and its related impact on food choices, International Journal of Consumer Study, 29(6):508-514.

Blythe, J. (2008). Consumer Behavior. London: Thomson learning.

Butkeviciene, V., Stravinskiene, J. and Rutelione, A. (2008). Impact of Consumer Package Communication on Consumer Decision Making Process, Inzinerine Ekonomika-Engineering Economics, 1:57-65.

Deliya, M. (2012). Consumer Behavior towards the New Packaging of FMCG Products, Journal of Research in Commerce and Management, 1(11).

Deliya, M. and Parmar, B. (2012). Role of Packaging on Consumer Buying Behavior - Patan District, Global Journal of Management and Business Research, 12(10).

Dovaliene, A., Kuvykaite, R. and Navickiene, L. (2009). Impact of Package Elements on Consumer's Purchase Decision, Economics and Management.

Kotler, P. (2000). Marketing Management. New Jersey: Prentice Hall.

Kotler, P. and Armstrong, G. (2004). Principles of Marketing. United States of America: Pearson Education.

Lifu, F.L. (2012). An Analysis of the Effect of Product Packaging on Consumers' Buying Choice in Calabar Municipality, Cross River State, Nigeria, Asian Journal of Business Management, 4(2):186-191.

Rundh, B. (2005). The Multi-faceted Dimensions of Packaging, British Food Journal, 107(9):670-684.

Scott, Y. (2008). Packaging and the Environment: A Cross-cultural Perspective, Design Management Review, 19:42-48.

Silayoi, P. and Speece, M. (2004). Packaging and Purchase Decisions: An Exploratory Study on the Impact of Involvement Level and Time Pressure, British Food Journal, 106(8):607-628.

Smith, P. and Taylor, J. (2004). Marketing Communications: An Integrated Approach. London: Kogan Page.

Terblanche, N.S. (2006). An Application of the American Consumer Satisfaction Index in the South African Motor Vehicle Industry, South African Journal of Business Management, 37(4):29-38.

Ulrich, R.O., Campana, D. and Malkewitz, K. (2010). Formation of Consumer Price Expectation based on Package Design: Attractive and Quality Routes, Journal of Marketing Theory Practice, 18(1):23-40. 


\section{APPENDIX}

\section{Questionnaire}

This questionnaire is for a research paper designed to assess the impact of packaging on consumer buying behavior at Dhaka city in Bangladesh. Your information will be kept confidential and the responses will be aggregated for analysis. The researcher appreciates your participation.

Name:
Age:
1. $(18-25)$
2. $(26-35)$
3. $(36-45)$
4. (45 - Above)
Gender:
1. Male
2. Female
Occupation:
1. Business
2. Service
3. Others

$\begin{array}{lll}\text { Your buying behavior is dependent on packaging: } & \text { 1. Yes } & 2 \text {. No }\end{array}$

In the following scale, SA defines Strongly Agree, A defines Agree, N defines Neutral, D defines Disagree and SD defines Strongly Disagree. Please put one mark for each statement.

\begin{tabular}{|l|l|l|l|l|l|}
\multicolumn{1}{l}{ SA } & A & N & D & SD \\
\cline { 2 - 5 } \multicolumn{1}{l|}{} & 5 & 4 & 3 & 2 & 1 \\
\hline 1. Packaging color affects you to purchase products. & & & & & \\
\hline 2. Background image influences you to purchase products. & & & & & \\
\hline $\begin{array}{l}\text { 3. Packaging material is an essential element in your buying } \\
\text { behavior. }\end{array}$ & & & & \\
\hline 4. You consider the font style in case of purchasing products. & & & & & \\
\hline $\begin{array}{l}\text { 5. Design of wrapper is an important element in your buying } \\
\text { behavior. }\end{array}$ & & & & \\
\hline 6. You always look for printed information of the products. & & & & & \\
\hline 7. Innovation of packaging influences you to purchase products. & & & & & \\
\hline
\end{tabular}

Thank You for Your Participation

$--0--$

Publish Online and Print Version Both

ISSN Online: 2307-9592 